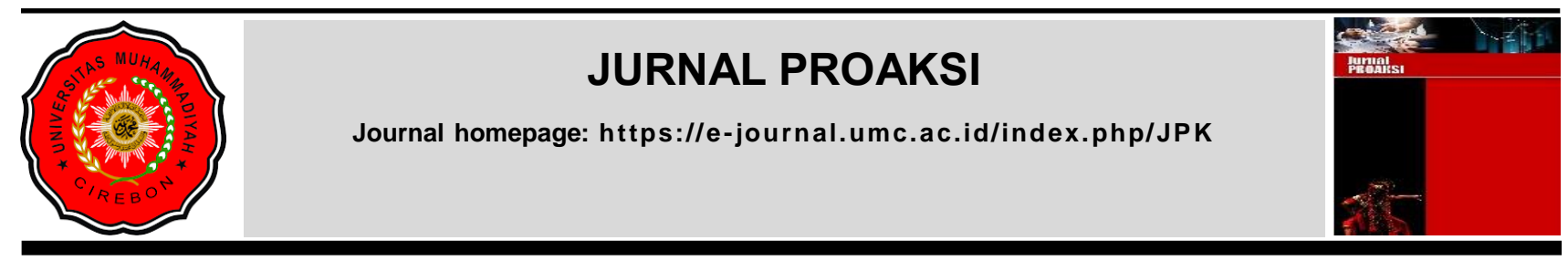

\title{
EVALUASI KINERJA REFORMASI AKUNTANSI SEKTOR PUBLIK PADA PEMERINTAH KABUPATEN SIDOARJO DENGAN PENDEKATAN KUALITATIF
}

\author{
Asvi Maschuroh ${ }^{1}$ \\ Hero Priono $^{2 *}$ \\ ${ }^{1}$ Magister Akuntansi,Universitas Pembangunan Nasional Veteran (UPN),Surabaya, East Java, Indonesia, \\ Email: vieasvi@gmail.com \\ ${ }^{2}$ Magister Akuntansi, Universitas Pembangunan Nasional Veteran (UPN), Surabaya, East Java, Indonesia \\ *Corresponden Author : heropriono1161@gmail.com
}

Diterima : 7 Juli 2021

Direvisi : 10 Agustus 2021

Dipublikasikan : 17 Oktober 2021

\begin{abstract}
Abstrak
Artikel ini menjelaskan pelaksanaan reformasi akuntansi sektor publik pada pemerintah daerah dalam memperkuat akuntabilitas yang diwujudkan dalam system inovasi pelayanan publik. Inovasi pelayanan publik ini masih perlu pengembangan dan pendampingan dalam mencapai tujuan untuk meningkatkan tata kelola pemerintahan dan pencegahan korupsi. Peningkatan akuntabilitas dalam pemerintah daerah merupakan tujuan penting dari pembaruan sistem akuntansi dan administrasi publik. Riset ini bermaksud untuk mengetahui hasil evaluasi apa saja yang diperoleh dari pelaksanaan reformasi akuntansi sektor publik pada pemerintah Kabupaten Sidoarjo. Informan dalam riset ini yaitu aparatur sipil negara pada Dinas Penanaman modal dan PTSP, Kecamatan Sukodono, Disduk Capil dan RSUD Kabupaten Sidoarjo. Riset ini merupakan jenis kualitatif interpretif. Penerapan desentralisasi di Indonesia ditandai dengan meningkatnya korupsi di Indonesia. Akuntabilitas merupakan kunci keberhasilan desentralisasi dalam pengambilan keputusan pada pemerintah daerah, desentralisasi memperkuat partisipasi warga negara dengan meningkatkan akuntabilitas pemerintah. Dengan adanya akuntabilitas publik diharapkan dapat menambah bentuk tanggung jawab pemimpin kepada rakyat. Selain itu rakyat juga dapat berpartisipasi dalam mewujudkan sistem pelayanan publik yang efektif, efisien dan akuntabel.
\end{abstract}

\section{Kata Kunci: Reformasi Akuntansi, Akuntabilitas, Desentralisasi, Korupsi}

\section{PENDAHULUAN}

Dalam rangka pengelolaan pelayanan publik, aparatur sipil negara berkewajiban memberikan pelayanan berkualitas kepada masyarakat. Pelayanan berkualitas merupakan kunci utama karena akan mencerminkan nilai dan karakteristik pemerintahan itu sendiri.Pokokpemerintahan saat ini yang perlu diperbarui sistemnya adalah birokrasi (Nurwindiarti, 2016). Birokrasi merupakan instrumen dalam pengelolaan pelayanan yang dilakukan oleh pemerintah. Birokrasi memegang peranan penting dalam memutuskan apakah pelayanan yang diberikan sudah berkualitas atau belum. Namun asal- usul sebelumnya telah mengakibatkan beberapa masalah seperti kewenangan terpusat dan pelayanan dengan pungutan liar, maka dibentuklah suatu otonomi daerah.

Salah satu karakter pemerintahan yang bagus adalah adanya akuntabilitas dan pengembangan pelayanan publik, selain keterbukaan dan tegaknya aturan pemerintah. Oleh sebab itu, diperlukan pengawasan manajemen pemerintahan untuk mendukung terciptanya akuntabilitas dalam pemerintahan. Sebagai konsekuensi dari pemerintahan yang baik yaitu terciptanya pelayanan publik yang berkualitas. Apabila pelayanan yang diberikan bagus dan mampu mencukupi kebutuhan 
masyarakat, maka masyarakat akan merasakan kepuasan dan menilai bahwa pelayanan yang diterimanya berkualitas (Putra, 2018).

Dalam sepuluh tahun terakhir, pembangunan manusia di Indonesia terus mengalami sedikit kemajuan, pada tahun 2020 berada di peringkat ke 107 dari 189 negara yang sudah dianalisis oleh UNDP. Tetapi, jika melihat skor IPM RI versi UNDP nilainya termasuk tinggi. Indonesia menduduki peringkat kelima di kawasan Asia Tenggara. IPM Indonesia dikalahkan oleh Singapura, Brunei Darussalam, Malaysia dan Thailand. Negara - negara ASEAN jika dibandingkan dengan indonesia masih lebih unggul di semua aspek. Indonesia diharuskan selalu ber-improve untuk menambah nilai pemberdayaan sumber manusianya. Pemerataan ekonomi diseluruh pulau dan tidak hanya jawa saja juga perlu diperhatikan (CNBC Indonesia, 2020).

Tabel 1.

Indeks Pembangunan Manusia (IPM) Indonesia Tahun 2020

\begin{tabular}{lccc}
\hline \multicolumn{1}{c}{ Negara } & Ranking & IPM & GNI/Kapita \\
\hline Vietnam & 117 & 0.704 & $7.43 \mathrm{~K}$ \\
Thailand & 79 & 0.777 & $17.78 \mathrm{~K}$ \\
Singapura & 11 & 0.938 & $88.16 \mathrm{~K}$ \\
Myanmar & 147 & 0.583 & $4.96 \mathrm{~K}$ \\
Malaysia & 62 & 0.81 & $27.53 \mathrm{~K}$ \\
Laos & 137 & 0.613 & $7.41 \mathrm{~K}$ \\
Kamboja & 144 & 0.594 & $4.25 \mathrm{~K}$ \\
Indonesia & 107 & 0.718 & $11.46 \mathrm{~K}$ \\
Filiphina & 107 & 0.718 & $9.78 \mathrm{~K}$ \\
\hline
\end{tabular}

Sumber : CNBC Indonesia

Sebagai pemutus mampu bersaing atau tidak, inovasi menjadi ide yang kerap dibicarakan pada segala bidang usaha. Pada umumnya pegawai yang bekerja di pemerintah hanya menjalankan SOP Sistem Operasional Prosedur) secara datar - datar saja (Suwarno, 2008). Oleh karenanya, "sebuah kualitas pelayanan publik merupakan cerminan dari sebuah kualitas birokrasi pemerintah" yangmerupakan hasil dari pergeseran pola piker tentang pelayanan publik. Pada riset ini objeknya adalah Satuan Kerja Perangkat Daerah pada Kabupaten Sidoarjo yang masuk dalam penerapan role model pelayanan smart city dan menerima penghargaan "role model" Penyelenggaraan Pelayanan Publik "Kategori A" pada Pemerintah Kabupaten Sidoarjo. Antara lain : Dinas Penanaman Modal dan PTSP Kabupaten Sidoarjo, Disduk Capil Kabupaten Sidoarjo, RSUD Kabupaten Sidoarjo dan Kecamatan Sukodono. Dengan layanan "smart city" ini seluruh informasi dan aktivitas pemerintahan, pengembangan, penyusunan dan kemasyarakatan Pemerintah Kabupaten Sidoarjo bisa diakses oleh warga Sidoarjo. (Infopublik.id, 2017).

Tabel 2.

Perkembangan Capaian IGG Kabupaten Sidoarjo Tahun 2016-2018

Terhadap Target RPJMD Kabupaten Sidoarjo Tahun 2016-2021

\begin{tabular}{lcccccc}
\hline \multirow{2}{*}{ Indikator Kinerja Utama } & \multicolumn{6}{c}{ Target Pencapaian } \\
\cline { 2 - 7 } & 2016 & 2017 & 2018 & 2019 & 2020 & 2021 \\
\hline Indeks Good Governance & 65,35 & 66,31 & 67,33 & 69,32 & 69,55 & 70,76 \\
\hline & 65,35 & 63,69 & 69,19 & & \\
\hline Indeks Reformasi Birokrasi & & & $\mathrm{B}$ & $\mathrm{B}$ & $\mathrm{B}$ & $\mathrm{B}$ \\
\hline
\end{tabular}

Sumber : Bappeda Kabupaten Sidoarjo, 2018

Memperhatikan grafik di atas, terlihat bahwa capaian IGG (Indeks Good Governance) Kabupaten Sidoarjo pada tahun 2018 telah melampaui target dalam RPJMD Kabupaten Sidoarjo Tahun 2016 - 2021. Di sisi lain reformasi birokrasi merupakan langkah strategis untuk membangun aparatur negara agar lebih berdaya guna dan berhasil guna dalam mengemban tugas umum pemerintahan dan pembangunan nasional. Salah satu instrumen untuk mengukur keberhasilan reformasi birokrasi adalah IRB (Bappeda Kabupaten Sidoarjo, 2019). 
Birokrasi memiliki peran strategis dalam menentukan apakah suatu pelayanan yang diberikan telah berkualitas atau belum. Namun pengalaman sejarah telah menimbulkan masalah seperti sentralisasi kekuasaan dan pelayanan yang penuh dengan pungutan liar, maka dibentuklah suatu otonomi daerah yang tidak lagi bergantung pada pemerintah pusat sehingga sentralisasi pemerintahan dapat dihindarkan. Oleh karena itu tanggung jawab serta kewenangan pemerintah daerah sangat besar dalam kaitannya dengan penyelenggaraan publik. Kewenangan tersebut semestinya dipergunakan untuk meningkatkan kualitas pelayanan publik dan kesejahteraan masyarakat (Nurwindiarti, 2016).

Hal ini menunjukkan langkah lanjutan yang ada pada otonomi daerah, yaitu peraturan yang menegaskan jika setiap daerah mempunyai wewenangnya sendiri dalam mengkooridinir urusan pemerintah dan juga dalam mengelola pelayanan untuk masyarakat seperti UU yang masih berlaku (Rizky, et al, 2019). Pemerintah mengharapkan ada beberapa perubahan akan transparansi dan akuntabilitas dalam mengelola keuangan milik negara dan mengikuti best practices yang sudah disesuaikan dengan keadaan Indonesia saat ini (Satrio, Yuhertiana, \& Hamzah, 2016).

Akuntabilitas kinerja instansi pemerintah daerah merupakan salah satu bagian isu kebijakan yang strategis di Indonesia saat ini, karena perbaikan akuntabilitas kinerja instansi pemerintah berdampak pada upaya terciptanya good governance. Kebijakan tersebut menghasilkan informasi tentang akuntabilitas kinerja instansi pemerintah yang dibutuhkan, karena dengan informasi ini pemerintah mempunyai bahan dalam pengambilan keputusan untuk melakukan perbaikan-perbaikan manajemen dalam penyelenggaraan urusan pemerintahan yang lebih baik (Santoso \& Pambelum, 2008). Namun, rendahnya akuntabilitas kinerja instansi-instansi pemerintah menyebabkan Indonesia sebagai salah satu Negara di Asia yang mengalami pelambatan pertumbuhan ekonomi. Hal itu tidak lain karena kepala daerah dengan otoritas lokal belum mengidentifikasikan dan menyediakan kebutuhan warga untuk pelayanan publik. Sehingga pencegahan perilaku korup pejabat dan politisi dapat dimaksimalkan.

Kabupaten Sidoarjo merupakan salah satu Kabupaten yang berada di Provinsi Jawa Timur. Kabupaten Sidoarjo menjadi salah satu kota perekonomian Provinsi Jawa Timur karena terdapat berbagai potensi usaha pada bidang industri, perdagangan, pariwisata dan usaha - usaha kecil menengah serta letak wilayah yang strategis dan sumber daya manusia yang memadahi. Maka perkembangan Kabupaten Sidoarjo mampu menjadi daerah yang menjanjikan bagi perkembangan ekonomi regional. Tetapi sangat disayangkan, perkembangan tersebut tidak dibarengi dengan penerapan serta pelaksanaan akuntansi sektor publik di setiap Organisasi Perangkat Daerah, sehingga masih ditemukan belum memadainya lembaga pelayanan di Kabupaten Sidoarjo. Beberapa hal berikut merupakan hal - hal yang telah menginspirasi peneliti dalam mengevaluasi kinerja reformasi akuntansi sektor publik yang kedepannya akan menjadi lebih baik pada akuntansi pemerintahan kabupaten sidoarjo.

Dengan adanya latar belakang seperti yang dijabarkan diatas, dapat ditarik hipotesis yang dinyatakan sebagai berikut :

1. Bagaimana dampak pelaksanaan reformasi akuntansi sektor publik pada Pemerintah Kabupaten Sidoarjo dari sisi akuntabilitas kinerja?

2. Bagaimana dampak pelaksanaan reformasi akuntansi sektor publik pada Pemerintah Kabupaten Sidoarjo dari sisi pencegahan fraud?

3. Bagaimana dampak negatif yang timbul atas pelaksanaan reformasi akuntansi sektor publik pada Pemerintah Kabupaten Sidoarjo?

4. Bagaimana cara mengantisipasi dampak negatif dari pelaksanaan reformasi akuntansi pada sektor publik pada Pemerintah Kabupaten Sidoarjo?

\section{KAJIAN PUSTAKA}

Berbicara mengenai pelaksanaan reformasi akuntansi sector public, salah satunya pelayanan public yang mudah dan dapat diakses oleh masyarakat sehingga tujuan pemberi dan penerima layanan dapat tercapai dengan baik. Indonesia (Mardiasmo, 2006) dalam melaksanakan kebijakan otonomi dan desentralisasi menerapkan pendekatan modern yang disebut New Public Management (NPM). Implikasi dari mengadopsi model tersebut adalah melakukan serangkaian reformasi di sector public yaitu reformasi anggaran, reformasi manajemen, reformasi audit serta reformasi kelembagaan. Reformasi akuntansi sector public dapat terealisasi dengan baik apabila diikuti oleh sumber daya manusia yang kompeten, dukungan informasi teknologi, budaya kerja yang kondusif serta penegakan hukum dan 
lembaga yang dirancang. Akuntanbilitas kinerja (Santoso \& Pambelum, 2008) instansi pemerintah merupakan salah satu kebijakan strategis untuk perbaikan kinerja yang berdampak terciptanya good governance. Penerapan akuntansi sector public dan pengendalian kualitas laporan keuangan akan berdampak pada peningkatan akuntanbilitas kinerja unit pemerintah dan penghindaran bentuk penipuan.

Kurniawan (2011) dalam penelitiannya memberi gambaran bahwa desentralisasi demokrasi harus didampingi dengan peningkatan jumlah orang yang terlibat dalam penindakan korupsi. Setidaknya ada tiga penyebab utama kepala daerah melakukan korupsi, keluasaan kepala daerah dalam mengelola APBD, pemanfaatan jabatan yang sarat dengan minat politik, serta pengadaan barang jasa yang tidak sesuai prosedur. Untuk meredam celah korupsi yang dilakukan kepala daerah perlu perbaikan mekanisme akuntabilitas, transparansi dan partisipasi public serta pengawasan berkala dari pemerintah pusat.

\section{Teori KeagenandanTeori Pilihan Publik}

Pola pikir dari teori keagenan ini menjabarkan jika organisasi sebagai suatu hubungan kerjasama antara pemegang saham (principal) dan manajer (agent) dengan berlandaskan kontrak yang telah ditanda tangani oleh kedua belah pihak (Jensen dan Meckling, 1976 dalam Cantabene et al, 2014). Dilihat dari teori diatas, hubungan yang terjalin diantara pemerintah dengan masyarakat mempunyai koneksi yang sama dengan hubungan principal danagen. Pemerintah merupakan agen dan masyarakat adalah principal nya. Agen diberikan wewenang dan sumber daya oleh para pincipal. Sebagai wujud pertanggung jawaban, agen memberikan laporan pertanggung jawaban pada principal, karena ("terjadi asimetri informasi") pihak ketiga dibutuhkan principal untuk meyakinkan jika yang dilaporkan oleh agen adalah benar atau tidak. Akuntansi sector publik inilah yang diharapkan mempunyai peranan besar sebagai pihak ketiga. Sektor Publik adalah suatu entitas yang aktifitasnya berhubungan dengan usaha untuk menghasilkan barang dan pelayanan publik, dalam rangka memenuhi kebutuhan hak publik.

Teori pendukung yaitu teori pilihan publik. Teori ini menjelaskan, "bagaimana pemerintah membuat keputusan terkait dengan kepentingan masyarakat publik" (Samuelson \& Nordhaus, 1995). Teori ini mempunyai focus untuk memecahkan masalah individu demi keuntungan yang akan diperoleh untuk Bersama melalui politisi dan birokrat yang sudah dipilih oleh rakyat sekitar. Teori dapat digunakan sebagai petunjuk bagi pengambilan keputusan dalam penentuan pilihan kebijakan publik yang paling efektif. Masyarakat akan memilih kebijakan yang benar-benar dapat mewakili kebutuhan mereka.

\section{NPM Dan Reformasi Akuntansi Sektor Publik}

New Public Management (NPM) merupakan paradigma baru dalam tata kelola sektor public yang pertama kali dikembangkan pada 1980-an di Selandia Baru, Inggris dan Amerika Serikat yang berimbas dari krisis kesejahteraan negara. Perspektif adminisrasi publik "New Public Management", menggunakan pendekatan sector swasta dan pendekatan bisnis dalam sektor publik (Puspawati, 2016). Asumsi NPM adalah mengenalkan insentif akan persaingan pasar dan asas manfaat sejalan dengan kinerja, dan memberikan hasil akuntabilitas yang lebih baik dibandingkan birokrasi administrasi publik yang lama. "New Public Management sebagai filsafat publik baru, sebagai langkah menuju pendekatan pemerintahan yang menempatkan penekanan pada transparansi, manajemen kinerja dan akuntabilitas pegawai dan manajer sektor publik" (Leishman et al., 1996, dalam Hayer, 2010).

\section{Akuntansi Sektor Publik}

Akuntansi sektor publik adalah kegiata berhubungan dengan akuntansi dalam sektor publik yang menyangkut masalah keuangan. Pemerintahan merupakan organisai sektor publik yang paling utama, karena itu akuntansi sektor publik juga bisa disebut sebagai kegiatan akuntansi yang diterapkan kepada pemerintahan, baik pemerintahan daerah atau pemerintahan pusat. Prespektif ilmu ekonomi juga memiliki pandangan yang sama.

\section{Kecurangan (Fraud)}

Penyimpangan adalah kata lain dari fraud, begitu juga dengan istilah error dan irregularities masing - masing kata mempunyai makna sebagai anomali atau penyimpangan (Dewi dan Apandi, 2012). Fraud (Kecurangan) merupakan sebuah objek yang telah dijadikan musuh oleh akuntansi forensik. Kecurangan merupakan sebuah kegiatan yang melibatkan kecerdikan sebuah manusia didalam sebuah kegiatan, yang dipakai seseorang untuk mencari keuntungan sendiri dari orang lain dengan cara 
yang salah. Kecurangan merupakan kegiatan penipuan, pada umumnya berbentuk sebagai kebohongan, scam dan pemalsuan.

\begin{abstract}
Akuntabilitas
Menurut LAN dan BPKP (LAN \& BPKP, 2000), "akuntabilitas kinerja adalah kewajiban untuk memberikan pertanggung jawaban atau menjawab dan menerangkan kinerja dan tindakan seseorang / badan hukum / pimpinan suatu organisasi kepada pihak yang memiliki hak atau berkewenangan untuk meminta keterangan atau pertanggung jawaban". Dengan adanya pernyataan diatas maka instansi pemerintah, bagian atau lembaga negara di pusat maupun daerah sesuai dengan tugas pokok masing masing diharapkan dapat memahami lingkup akuntabilitasnya sendiri, karena kegagalan atau sebuah keberhasilan dari misi - misi yang dimiliki instansi tersebut adalah akuntabilitas yang diminta.
\end{abstract}

\title{
Desentralisasi
}

Desentralisasi merupakan penyerahan tugas dari pemerintah pusat kepada pemerintah didaerah dalam mengurusi masalah - masalah yang ada di setiap daerah. Berdasarkan undang-undang nomor 32 tahun 2004 tentang Pemerintahan Daerah, "desentralisasi dimaknai sebagai penyerahan wewenang pemerintah oleh pemerintah kepada daerah otonom untuk mengatur dan mengurus urusan pemerintahan dalam sistem Negara Kesatuan Republik Indonesia". Desentralisasi didaerah dapat dilihat dengan adanya otonomi daerah, dimana pemerintah memberikan wewenang kepada pemerintah daerah untuk menanggulangi masalah didaerah.

\section{Pencegahan Fraud dengan Desentralisasi Akuntansi Sektor Publik}

Isu desentralisasi pasti disandingkan dengan efisiensi dan inovasi, karena melewati desentralisasi bisa melewati beberapa tahap dalam birokrasi. Inovasi terbuka, dikarenakan adanya wewenang untuk membuat suatu keputusan yang paling rendah. Di mana ada desentralisasi/keleluasaan untuk mengambil keputusan, maka di situ ada peluang untuk mengembangkan inovasi. "keuntungan penerapan sistem desentralisasi antara lain, mengurangi bertumpuknya pekerjaan pusat di daerah, tidak perlu menunggu instruksi dari pusat untuk pekerjaan yangsegera diselesaikan, mengurangi birokrasi dalam arti yang buruk, mengurangi kesewanang - wenangan dari pemerintah pusat dan akan memperbaiki kualitas pelayanan" (Simanjuntak, 2015).

Hingga saat ini, sektor publik dinilai oleh masyarakat sebagai bidang yang melakukan pemborosan, tidak efisiensi dan juga sumber dari kebocoran dana. Sektor publik diberi tuntutan baru agar lebih memperhatikan value of money dan juga tidak lalai dalam mengawasi output, input dan outcome. Implementasi konsep value for money dapat membenahi akuntabilitas dari sektor publik dan diharapkan dapat menigkatkan efektifitas dari layanan publik agar performa sektor publik menjadi lebih baik, memperbaiki kualitas layanan publik, memperkecil biaya keluar dengan ditekankan untuk efektifitasnya dan meningkatkan kesadaran dalam menggunakan uang publik (public costs awareness) (Mardiasmo, 2006).

Istilah privatisasi atau "menjadikan privat", mengganti kontrol yang tadinya merupakan kontrol publik menjadi privat. Tetapi, istilah ini mempunyai arti yang lebih beragam; privatisasi adalah hal yang dilakukan untuk mengurangi turun tangan pemerintah dalam asset publik atau menambah wewenang sektor privat dalam menangani aset publik, yang artinya memberikan pemerintah kewenangan yang lebih sedikit dan memperbanyak peran masyarakat pada saat merumuskan apa saja yang dibutuhkan mereka. Kemitraan diantara sektor publik dan privat atau public-privat partnership $(P P P)$ saat ini telah menjadi standard konsep dalam lingkungan pemerintahan lokal.

\section{Penerapan Akuntansi Sektor Publik Dalam Memperkuat Akuntabilitas Kinerja Pemerintah Daerah}

Akuntabilitas kinerja adalah salah satu kunci yang bisa mewujudkan pengelolaam tata pemerintahan yang baik. Pamungkas (2012) menjabarkan jika penerpan dari akuntansi sektor publik mempunyai pengaruh akan akuntabilitas performa intansi pemerintah. Instansi pemerintah mulai menerapkan akuntansi yang baik dalam harapan dapat membenahi akuntabilitas performa instansi pemerintah jadi performa dalam menyelenggarakan aktivitas pemerintah dapat berjalan dengan baik. Kesimpulannya pemerintah dapat mengambil dari informasi keuangan pemerintah dalam membuat keputusan dan terciptanya transparansi dalam akuntabilitas publik (Pratiwi \& Setyowati, 2017). 


\section{METODE PENELITIAN}

Penelitian ini menggunaka nmetode kualitatif dengan pendekatan interpretif. Paradigma interpretif menganggap realitas sosial secara holistik, berdampingan dengan satu dan lainnya. Disandingkan dengan peran ilmu sosial, menurut Hendrarti (2010) "paradigma interpretif memandang bahwa ilmu sosial sebagai analisis sistematis atas 'socially meaningful action' melalui pengamatan langsung terhadap aktor sosial dalam latar alamiah agar dapat memahami dan menafsirkan bagaimana para aktor sosial menciptakan dan memelihara dunia sosial mereka". Wawancara langsung dengan responden dijadikan sebagai data primer. Informan dalam penelitian ini dipilih dengan menggunakan teknik Cluster Sampling, dimana setiap anggota kelompok dari kelompok (cluster) Dinas yang menjadi role model inovasi pelayanan public Kabupaten Sidoarjo, yaitu Dinas Penanaman Modal \& PTSP, Disduk Capil, RSUD dan Kecamatan Sukodono.

\section{Fokus penelitian}

Penelitian ini difokuskan pada Organisasi Perangkat Daerah (OPD) dan Badan Layanan Umum Daerah (BLUD) Kabupaten Sidoarjo yang masuk dalam penerapan role model pelayanan smart city dan meraih penghargaan sebagai role model Penyelenggaraan Pelayanan Publik "Kategori A". Dalam hal ini, Dinas Penanaman Modal dan PTSP; Disdukcapil; RSUD dan Kecamatan Sukodono. Pada pendekatan kualitatif interpretif, peneliti akan mengobservasi dan mewawancara informan yang dianggap memiliki kapasitas dan pengetahuan dalam memberikan informasi tentang bagaimana Sistem Kerja Inovasi Pelayanan Publik Kabupaten Sidoarjo dengan secara mendalam dan komprehensif, sehingga memperoleh hasil penelitian yang fokus dengan tujuan yang telah ditetapkan.

\section{Teknik Pengumpulan Data}

Tehnik Pengumpulan data yang dilakukan tentunya juga terkait dengan masalah dan tujuan penelitian. Berbagai teknik pengumpulan data dapat digunakan untuk memperoleh data penelitian yang akurat dan valid. Dalam penelitian ini, penulis menggunakan rancangan pengumpulan data dapat dilakukan dengan interview (wawancara), dokumentasi, observasi (pengamatan), dan gabungan ketiganya (Sugiyono, 2018).

\section{Teknik Analisis Data}

Analisis data dalam penelitian kualitatif dilakukan sejak sebelum memasuki lapangan, selama di lapangan, dan setelah selesai di lapangan (Sugiyono, 2018). Pengumpulan data merupakan kegiatan untuk mengumpulkan data dari informan secara langsung, baik dari dokumen atau arsip yang terkait. Adapun tahapan alur analis data yang dilakukan dalam penelitian kualitatif tentang ini adalah sebagai berikut :

1. Mereduksi data, memilih hal-hal yang pokok, memfokuskan pada hal-hal yang penting, dicari tema dan polanya. Sehingga data yang telah direduksi akan memberikan gambaran yang lebih jelas, dan mempermudah peneliti untuk melakukan pengumpulan data selanjutnya.

2. Mendisplaykan data, yang akan memudahkan untuk memahami apa yang terjadi, merencanakan kerja selanjutnya berdasarkan apa yang telah dipahami tersebut.

3. Penarikan kesimpulan dapat dilakukan berdasarkan hasil penelitian yang dilakukan dan telah ada dengan memperhatikan hasil wawancara, dan dokumentasi berupa data-data awal yang belum siap digunakan dalam analisis, setelah data tersebut direduksi dan disajikan.

\section{HASIL DAN PEMBAHASAN}

\section{Pelaksanaan Reformasi Akuntansi Sektor Publik Pada Pemerintah Kabupaten Sidoarjo Dari Sisi Akuntabilitas Kinerja}

Pelaksanaan reformasi akuntansi sektor publik pada pemerintah kabupaten sidoarjo dari sisi akuntabilitas kinerja dapat dikatakan cukup memadai dilihat dari prestasi yang diperoleh pemerintah kabupaten Sidoarjo dalam pelaksanaan reformasi inovasi pelayanan publik yang memudahkan masyarakat dalam pengurusan administrasi kependudukan, layanan perizinan, layanan rumah sakit dan sebagainya. Adanya prosentasi kenaikan nilai investasi sebagai dampak pengembangan dan pemanfaatan e-government bagi instansi pelayanan publik merupakan wujud terperhatikannya akuntabilitas kinerja instansi pemerintah daerah sebagai upaya peningkatan efisiensi dan produktifitas kinerja pemerintah daerah. Hal ini sejalan dengan penelitian yang dilakukan oleh (Puspawati, 2016) yang terbukti meningkatkan kualitas pelayanan publik pada pemerintah kabupaten Sidoarjo. 


\section{Pelaksanaan Reformasi Akuntansi Sektor Publik Pada Pemerintah Kabupaten Sidoarjo Dari Sisi Pencegahan Fraud}

Pengembangan sistem deteksi fraud bukan merupakan hal yang mudah untuk dilakukan karena melibatkan teknologi baru, penambahan fitur alat bantu hitung untuk perhitungan retribusi pada pemrosesan IMB adalah satu bentu pencegahan fraud. Namun, apabila dikaitkan dengan pelaksanaan reformasi dalam pelayanan publik masih dikatakan kurang memadai, karena fitur tersebut masih harus memiliki kecerdasan yang terus berkembang seiring dengan proses pelayanan dengan indikatorindikator yang dapat mendeteksi adanya kecendrungan fraud. Pernyataan diatas mendukung penelitian (Hamidah \& Kristiani, 2020) yang menjelaskan bahwa penerapan akuntansi sektor publik dapat mencegah terjadinya fraud pada sektor publik di era digital jika dilaksanakan dengan mempertimbangkan beberapa indikator yang mempengaruhi fraud, seperti performance accountability, dan melakukan strategi teknis, pendekatan dua paradigma, dan strategi preventif.

\section{Dampak Negatif Atas Pelaksanaan Reformasi Akuntansi Sektor Publik}

Tidak tersedianya informasi mengenai indikator kinerja birokrasi publik menjadi bukti dan ketidakseriusan pemerintah pusat untuk menjadikan kinerja pelayanan publik sebagai agenda kebijakan yang penting. Sehingga pengembangan inovasi dalam suatu pemerintah daerah menjadi tanpa tujuan yang jelas dan berjangka pendek. Hal ini sejalan dengan penelitian yang dilakukan (Narsa, 2018) yang menyatakan kualitas birokrasi pemerintah merupakan cerminan dari kualitas pelayanan publik. Sehingga teori pilihan publik turut andil dalam hal ini dengan partisipasi masyarakat dalam proses peningkatan pelayanan publik.

\section{Antisipasi Dampak Negatif atas Pelaksanaan Reformasi Akuntansi Sektor public}

Penguatan sistem reformasi akuntansi pada pelayanan publik perlu ditingkatkan juga Perubahan sikap dan perilaku aparat pelayanan yang berorientasi kepuasan masyarakat agar mampu mendorong perubahan profesionalisme para penyedia layanan, serta peningkatan kualitas pelayanan. Kondisi sejalan dengan penelitian (Hasthoro \& Sunardi, 2016) yang menyatakan pelaksanaan reformasi pelayanan pada pemerintah daerah diukur dengan menggunakan transparansi, akuntabilitas pemerintah daerah, budaya hukum, dan partisipasi masyarakat sehingga semangat otonomi dan good governance yang diharapkan akan membawa pemerintahan ke arah yang lebih baik.

\section{KESIMPULAN}

Pelaksanaan reformasi akuntansi sektor public sebagai upaya Pemerintah Kabupaten Sidoarjo dalam meningkatkan kualitas pelayanan perizinannya sejauh ini untuk secara keseluruhan memiliki keuntungan relatif di dalamnya, diantaranya adalah Tingginya tingkat akuntabilitas kinerja yang berdampak meningkatnya prosentase pelaku usaha dalam berinvestasi, Kepercayaan masyarakat akan sistem sehingga mendukung terselenggaranya pelayanan publik yang bebas dari adanya korupsi dan juga bersih, Menurunkan jumlah laporan dugaan maladministrasi pelayanan publik sehingga tingkat pelayanan publik menjadi lebih efisien dan efektif dan Mengembangkan inovasi pelayanan sebagai bentuk responsibilitas untuk pemerintah dalam pembenahan pelayanan publik masyarakat pada bidang administrative.

\section{SARAN}

\section{Saran Teoritis:}

Untuk mengevaluasi kinerja organisasi dimasa yang akan datang disarankan agar organisasi tidak hanya menggunakan prosentase PAD selama 3 tahun dan prestasi yang diperoleh oleh suatu Pemerintah Kabupaten. Namun juga dapat menambahkan survey atas kepuasan masyarakat sebagai pengguna layanan dari suatu inovasi pelayanan publik.

\section{Saran Praktis:}

- Membangun ekosistem inovasi pada lingkungan pemerintahan sehingga terbentuk pola pikir ASN yang inovatif dan melayani. Pelayanan manual maupun digital harus memiliki standar operasional prosedur yang jelas dan real time.

- Melakukan benchmarking atau tolok ukur perbandingan dengan organisasi publik lainnya. Dengan mengadopsi dan memodifikasi yang telah dilakukan organisasi lain maka akan semakin melengkapi layanan digital yang sudah ada. 
- Untuk menanggulangi adanya error dalam suatu aplikasi perlu adanya kebijakan pembenahan administrasi dengan cara meminimalisasi prosedur sistem operasional atas permohonan suatu layanan, mempermudah pengisian e-form, serta menambahkan kolom saran dan masukan atas pelayanan yang diberikan pada suatu organisasi perangkat daerah. Sehingga dapat dijadikan sebagai salah satu bentuk pengambilan keputusan yang akurat untuk penyusunan RAPBD tahun berikutnya.

\section{REFERENSI}

Atmadja, A. T., \& Saputra, K. A. K. (2018). Kegagalan Akuntansi dalam Menanggulangi Fraud (Perspektif Postmodern). Jurnal Aplikasi Akuntansi (JAA).

Badan Perencanaan Pembangunan Daerah Kabupaten Sidoarjo. (2018). Data Dinamis Kabupaten Sidoarjo Triwulan I-2019.

Cantabene, C., Baraldi, L.A., \&Alfano, R.M. (2014). The Effect of The Decentralization Degree on Cooruption : A New Interpretation. Economics and Econometrics Research Institute.

CNBC Indonesia. (2020). diakses 1021. https://www.cnbcindonesia.com/news/20201216142816-4-209558/duh-indeks-pembangunanmanusia-ri-no-107-dari-189-negara/2

Dewi, Rozmita YR \& Apandi. 2012. Gejala Fraud dan Peran Auditor Internal dalam Pendeteksian Fraud di Lingkungan Perguruan Tinggi.

Djamhuri, A. (2006). New Public Management, Accounting Reform, And Institutional Perspective of Public Sector Accounting In Indonesia. Jurnal BisnisdanAkuntansi. https://doi.org/10.34208/jba.v8i3.240

Fitriyani, F., Arsiyah, A., \& UB, A. R. (2019). Berkas Mlaku Dhewe (BMW) untuk Peningkatan Pelayanan Publik di Kabupaten Sidoarjo. JKMP (Jurnal Kebijakan Dan Manajemen Publik). https://doi.org/10.21070/jkmp.v5i2.1316

Hendrarti, Dwi Windyastuti Budi. 2010. "Konsep Dasar dan Isu Penelitian Kualitatif", Makalah pada Pelatihan Metodologi Penelitian Kualitatif (Teori \& Praktek), oleh Fakultas Kedokteran Hewan: Universitas Airlangga, Surabaya, 9- 11 Februari 2010.

Hamidah \& Kristiyani, D. (2020). Model Penerapan Akuntansi Sektor Publik Untuk Mencegah Fraud Pada Sektor Publik Di Era Digital.Jurnal Bisnis Dan Akuntansi. https://doi.org/10.34208/jba.v22i2.732

Handriyan, P.Z., Akbar, I., Aji.R.G. (2020). Inovasi BadanPelayanan Perizinan Terpadu Kabupaten Sidoarjo Dalam Meningkatkan Kualitas Perizinan. Jurnal Administrasi Publik. Vol.2, No.1

Harun, H., Mir, M., Carter, D., \& An, Y. (2019). Examining the unintended outcomes of NPM reforms in Indonesia. Public Money and Management. https://doi.org/10.1080/09540962.2019.1580892

Hasthoro, H. A., \& Sunardi. (2016). Tata Kelola Publik dan Kinerja Keuangan Pemerintah Daerah di Indonesia. Jurnal Ekonomi Dan Bisnis, 19(1), 53-67.

Hayer, Garth den. 2010. New public management: A strategy for democratic police reform in transitioning and developing countries. Policing: An International Journal of Police Strategies \& Management Vol. 34 No.3, 2011 hal. 419-433.

Indrawati , Yuhertiana. (2008).Reformasi akuntansi sektor publik: mewujudkan pelayanan publik yang lebih baik melalui pelaporan keuangan pemerintahan yang akuntabel. Project report. LPPM UPN "Veteran" Jatim, Surabaya.

Infopublik.id. (2017). diakses 1 April 2021. https://infopublik.id/read/220106/bimtek-rencanapenerapan-smart-government-smart-living-dan-smart-society-.html

Kurniawan, T. (2011). Democratic Decentralization and Corruption in Indonesia ; Why Decentralization has Cause Head of Regions Affected by Corruption Cases. The 2011 Conference on Decentralization and Democratization in Southeast Asia, pp. 1-15.

LAN \& BPKP. 2000. Akuntabilitas dan Good Governance. Jakarta: Lembaga Administrasi Negara.

Mardiasmo. (2006). Perwujudan Transparansi dan Akuntabilitas Publik Melalui Akuntansi Sektor Publik: Suatu Sarana Good Governance. Jurnal Akuntansi Pemerintah. 
Narsa, N. P. D. R. H. (2018). Inovasi Pelayanan: Telaah Literatur Perbandingan Sektor Privat dan Sektor Publik. Berkala Akuntansi Dan Keuangan Indonesia, 3(2), 46. https://doi.org/10.20473/baki.v3i2.9871

Nurwindiarti, M. (2016). Efektivitas Sistem Informasi Pelayanan Perizinan Terpadu (SIPPADU) dalam Meningkatkan Kualitas Pelayanan Perizinan di Badan Pelayanan Perizinan Terpadu (BPPT) Kabupaten Sidoarjo. Kebijakan Dan Manajemen Publik ISSN 2303-341X, 4(1), 1-9.

Pamungkas, Bambang. 2012. Pengaruh Penerapan Akuntansi Sektor Publik dan Pengawasan Terhadap Kualitas Laporan Keuangan dan Implikasinya Terhadap Akuntabilitas Kinerja Instansi Pemerintah. Jurnal Ilmiah Ranggagading Volume 12, Nomor 2, Oktober $2012: 82-93$

Praditha, R., Kartini, K., \& Mande, H. (2017). Reformasi Akuntansi ; Mengapa Accrual Basis Lebih Baik?

Pratiwi, R. D., \& Setyowati, L. (2017). Determinan yang Mempengaruhi Akuntabilitas Kinerja Pemerintah Kota Semarang. Jurnal Bisnis Dan Ekonomi (JBE).

Portal Berita Info Publik. (2017). diakses 29 April 2021. https://infopublik.id/read/220106/bimtekrencana-penerapan-smart-government-smart-living-dan-smart-society-.htm

Puspawati, A. (2016). Penerapan New Public Management (NPM) di Indonesia (Reformasi Birokrasi, Desentraslisasi, Kerjasama Pemerintah dan Swasta Dalam Meningkatkan Pelayanan Publik)Perspectives in Management. PUBLISIA, 1(1), 38-53.

Putra, W. E. (2018). Analisis Pengaruh Pengawasan Fungsional, Akuntabilitas Publik Dan Peningkatan Pelayanan Publik Terhadap Kinerja Pemerintah Daerah (Studi Empiris Pada SKPD di Provinsi Jambi). Jurnal Akuntansi Dan Pajak. https://doi.org/10.29040/jap.v18i2.143

Republik Jatim. (2018). diakses 29 April 2021. https://republikjatim.com/baca/rombongan-kemenkeuri-belajar-ke-sidoarjo

Rizky, H. P., \& Setiawan, D. (2019). Perkembangan Penelitian Akuntansi Sektor Publik di Indonesia. Assets: Jurnal Akuntansi Dan Pendidikan. https://doi.org/10.25273/jap.v8i2.4647

Sari, D. P., Nurlinah, N., \& Irwan, A. L. (2017). Inovasi Pelayanan Perizinan dalam Peningkatan Pendapatan Asli Daerah (PAD) pada Kantor Pelayanan Terpadu Satu Pintu di Kota Makassar. Jurnal Administrasi Dan Kebijakan Kesehatan Indonesia.

Samuelson, Paul A. \& William D. Nordhaus. (1995). Makro-Ekonomi. Edisi keempat belas, Penerbit Erlangga, Jakarta.

Santoso, U., \& Pambelum, Y. J. (2008). Pengaruh Penerapan Akuntansi Sektor Publik Terhadap Akuntabilitas Kinerja Instansi Pemerintah Dalam Mencegah Fraud. Jurnal Administrasi Bisnis Unpar. https://doi.org/10.26593/jab.v4i1.363.

Satrio, M. D., Yuhertiana, I., \& Hamzah, A. (2016). Implementasi Standar Akuntansi Pemerintah Berbasis Akrual di Kabupaten Jombang. Jurnal Akuntansi Dan Keuangan, 18(1), 59-69. https://doi.org/10.9744/jak.18.1.59-70

Simanjuntak, K. M., Perencanaan, B., Daerah, P., Papua, P., Soa, J., Dok, S., \& Jayapura, I. I. (2015). Implementasi Kebijakan Desentralisasi Pemerintahan Di Indonesia Policy Implementation Decentralization Government In Indonesia. In Jurna Bina Praja.

Sugiyono. (2018). Metode Penelitian Kuantitatif Kualitatif dan R\&D. Bandung: Alfabeta

Suwarno, Yogi. (2008). Inovasi di Sektor Publik. Jakarta: STIA-LAN Press. 